Journal of Development and Communication Studies, Vol. 5. No. 2, July 2017 - June 2018

ISSN (Online \& Print): 2305-7432.

http://www.devcomsjournalmw.org.

\title{
Content of Vernacular Radio Stations Programs and Public Participation in Devolved Governance in Nyeri County, Kenya
}

\author{
Dorcas Wakio Mwangi, Caroline Biwott, David Gichuhi \\ Karatina University, Nyeri County, Kenya.Email: dorcasmwangi8@gmail.com
}

\begin{abstract}
Public participation in Kenyan counties still remains a mystery although many efforts have been put in place to achieve it. This is so because many county governments have documented use of public participation in governance without indicating a clear program to show how it is actualized. Media, including vernacular radio, is mentioned as one of the avenues for public participation but the question of how this happens remains unanswered. This study aimed to find out the influence of the content of vernacular radio stations programs on public participation in devolved governance. The study employed a mixed method research design. The target population was 661,156 Nyeri County residents and officials of vernacular radio stations that have listenership in Nyeri. The pyramid method developed by Krejecie and Morgan was used to arrive at the sample size of 384 county residents while purposive sampling technique was used to select Kameme FM and its three officials. Data was collected through questionnaires and interview guides. Quantitative data was analyzed using descriptive and inferential statistical techniques through Statistical Package for Social Sciences while Content Analysis was used to analyse qualitative data. Graphs and tables were used for presentations. The outcome was that there is a strong positive correlation between content of Vernacular Radio Stations Programs and public participation in devolved governance. The study recommends that more attention be given to content of these vernacular programs for they contribute to public participation in governance issues.
\end{abstract}

Key words: Public participation, vernacular radio programs, devolved governance, Nyeri, Karatina

https://dx.doi.org/10.4314/jdcs.v5i2.5

(C) 2018. The Author. This work is licensed under the Creative Commons Attribution 4.0 International License (CC-By-NC-ND). Users may freely share and redistribute this work provided that the author and the Journal of Development and Communication Studies are fully acknowledged. Users may not tweak or remix and offer this work for sale. The full license may be accessed at https://creativecommons.org/licenses/by-nc-nd/4.0/ 
There is global urge for good governance across the world (World Bank, 2015) as witnessed through renewed governance reforms that emphasize on devolution of power due to failure in centralized forms of government (Lodiaga, 2012). Consequently, public participation in devolved governments has been given much emphasis for it leads to successful governments as witnessed in the United States of America, United Kingdom, Brazil, India and South Africa. In Kenya, public participation is enshrined in the new constitution to ensure citizens engage in making decisions concerning issues and matters that affect them (Constitution of Kenya 2010, Article174c). This is after the centralization government failed to facilitate local solutions to local problems (Barret, Mude and Omiti, 2007). However, public participation remains a challenge in county governments. Community radio stations, in many countries and regions of the world, are recognized for their role in the advancement of good governance practices and especially in reaching out to the marginalized in the society who include the poor, women and children (UNESCO, 2008). Community radio stations promote citizen's access to information which enhances their participation in making decision at the county level. According to a survey by AfriMAP (2011), Kenya has a vast array of vernacular radio stations that make use of local languages in the dissemination of information and are also accessible in regions given little attention by the convectional commercial media. Due to this, vernacular radio stations can play a major role in informing the public on devolved governance processes and create platforms for public participation especially in marginalized areas which result in ensuring that diversity and pluralism of different views and opinions are heard.

\section{Statement of the Problem}

Article 10 (2) of the Constitution of Kenya (2010) provides that public participation is a national value and principle of governance. The Fourth Schedule of the Constitution obligates the county governments to facilitate the establishment of structures for citizen participation; among them information communication technology-based platforms. Therefore, county governments should use all forms of communication platforms especially the media to reach people and share all planned activities before a political decision is made. However, World Bank (2015) report shows that county governments in Kenya have failed to implement the provisions of the constitution Vernacular radio stations have the ability to reach a wide range of audience compared to any other form of medium because they broadcast in indigenous languages and are in areas neglected by the mainstream commercial media which mostly broadcast in English and Kiswahili (AfriMap, 2011) and are leading preferred media in Kenya (Kimutai, 2011). Therefore, the vernacular radio stations were mandated with the provision of information to the grassroots to make sure that every Kenyan has an understanding of devolution (Ogundiya, 2010). This study therefore aimed to explore the influence of content of vernacular radio stations programs on public participation in the devolved governance Nyeri County. This is because public participation seems below expectation despite its strong provision in the constitution and various efforts put in place to strengthen it.

\section{LITERATURE REVIEW}

\section{Public Participation in Devolved Governance in Kenya}

There is global urge for good governance across the world (World Bank, 2015) as witnessed through renewed governance reforms that emphasize on devolution of power due to failure in centralized forms of government (Lodiaga, 2012). Consequently, public participation in devolved governments has been given much emphasis for it leads to successful governments as witnessed in United States of America, United Kingdom, Brazil, India and South Africa. This is so because public participation has a wide range of advantages (Stivers, 2010).

According to the European Institute of Public Participation (2009), the governments of Europe have admitted facing difficulties in engaging large numbers of people and for participants to 
deliberate among themselves. It further notes that European governments that adopt boardroom strategies of public participation have failed to satisfy the majority of citizens and have therefore sparked protests from citizens who feel sidelined in the policy agenda formulation. In Germany, a feeling of mistrust has been created between the public and the government due to lack of a mutual governmental approach to participation due to the absence of an understanding of public participation that contains a strong sense of mutual help. According to the United Nations (2015), a clear public participation policy should be characterized by information disclosure, public inputs and communications. However, the World Bank (2015) reports that such characteristics are never practical in many African governments.

Moreover, public participation in Africa is something new and lacks proper guiding framework. For instance, the Constitution of South Africa has adequately provided for space and a favourable atmosphere for public participation in decision making processes at the local government level. However, these efforts have not yielded the expected results. Friedman (2004, cited in Nyaluzo (2006), agrees that public participation in issues of local governance has not been fully achieved although much effort has put in place by the government to create a favourable atmosphere for it. This, he adds, has been as a result of minimal consultation, accountability and transparency in the running of the local governments.

Nigeria, as other democratic societies, has embraced principles of good governance which entails public participation in her 1999 constitution. In an attempt to promote good governance, the Nigerian government came up with good governance hours by the mass media agencies to inspect the progress of work on the projects by both federal and national governments. This revealed a dependent relationship between good governance and media. Moreover, a study carried out in Nigeria on the role of the media in good governance revealed that the media has the potential to contribute to good governance if it espouses the basic principles of patriotism, accountability, transparency and objectivity in the discharge of its duties and upholds the truth and fairness at all times. However, despite the constitutional provision, enormous financial resources and huge potential of the country, good governance continues to be elusive in Nigeria (Dunu, 2013).

A study on 'Debating the Inconsistencies between Constitutional Provisions on Decentralization and Citizen Participation Realities in Zimbabwe' examined the constitution of Zimbabwe with the objective of showing its intentions of devolution. The study revealed that there is a strong gap between the constitutional intentions and practice. Citizen engagement idea has not been put into practice and the intentions of devolution have not been operationalized. The study recommended central government's political goodwill for putting into practice the provisions of the new constitution as a way of promoting public participation, democracy in governance and promotion of human rights (Chirisa \& Banduko, 2014). This is because the citizenry must be involved actively in the activities of the local government systems if the government of Zimbabwe must function effectively.

In Uganda, public participation is related to decentralization policy established in 1992 for it was believed that it would enhance democracy in local governance and rural development. This was through citizens taking part in decision-making on matters that are of concern to them; thus, enhancing responsiveness and accountability of the local government officials. However, the reality on the ground is different (Kiyaga \& Olum, 2009). A study on 'Local government citizen participation and rural development: Reflections on Uganda's decentralization system' revealed that some powers and functions have been devolved to local governments but the main objectives of decentralization seem far from reality for the public has shown little support in their role of raising resources for local development, fighting for accountability of their leaders and putting their leaders into positions of power without the control of the 'elite' in their societies. The study concludes that public participation in rural development in agricultural economies like Uganda is key. Therefore, the central government needs to encourage public participation in its development strategies so as to achieve a stable local ownership and empowerment (Kakumba, 2010).

In Kenya, public participation is enshrined in the new constitution to ensure citizens engage in making decisions concerning issues and matters that affect them (Constitution of Kenya 2010, Article174c). This is after the central government failed to facilitate local solutions to local problems 
such as inadequacies of service, misappropriation of public funds and corruption (Barret, Mude and Omiti, 2007). Kenya created room for more public participation which allows the government to regularly inform, consult and get feedback from its citizens on issues of governance. This is after timid devolved governance saw certain amount of public funds and some responsibilities such as in health, agriculture, rural and urban infrastructure taken to 47 county governments. Later, major decisionmaking processes were also shifted from the central to county governments. The constitution of Kenya allows its people to exercise this sovereign power of making decisions on matters that affect them directly or indirectly, that is, through representatives (Constitution of Kenya, 2010).

However, public participation remains a challenge in county governments in Kenya despite the many efforts. A baseline survey report on "The Status of Governance in Kenya" revealed that county governments in Kenya are aware of the premium the constitution has placed on public participation and have struggled to involve the citizens in decision making but poor strategies have frustrated the efforts. For instance, none of the counties has established a Compliant and Operational County Budget and Economic Forum and decentralization to sub counties, wards and villages have not been finalized in most counties. Moreover, none of the counties had a public participation policy or law; only Kakamega County had started the process of developing the law. This posed a great challenge to public participation.

A study on 'Challenges of Integrating Public Participation in Devolved System of Governance for Sustainable Development in Kenya' was carried out in Kericho, Bomet and Narok Counties (Ronoh et al., 2018). It revealed that public participation encounters difficulties such as popular negative attitudes, public lack of enthusiasm to take part, poor political goodwill, limited ability to participate, influence from politicians, demand for bribes and lack of time by the public to participate. It recommended that the people needed to change their mindset so as to better their opinion and raise their enthusiasm to participate

A World Bank (2015) report also shows that county governments in Kenya have failed to implement the provisions of the constitution as enshrined in the constitution. The study also revealed that there is a strong relationship between improved performance of governments and public participation but real performance of county governments of Kenya has remained poor. The Institute of Economic Affairs (2015) reports that absence of a Public Participation Act to ensure a legal framework for policy making in Kisumu County results in its lack of Public Participation Policy. As a result Nyeri County has been plagued by public protests due to implementation of unpopular policies, a clear indication that public participation is wrongly done in the region. In general, Kenyan county governments have been plagued by high level of unemployment, poor and inadequate infrastructure development and service delivery (Khaunya, Wawire and Chepngeno, 2015). This is indicated by the poor ranking of some counties, constant demonstrations and strikes, loss of trust and confidence in the devolved governments by the county residents due to their dissatisfaction (Cheema, 2007; Muriu, 2012). This has also resulted to poor public goodwill demonstrated by poor citizen-government relations at the county level (Transparency International, Kenya, 2015).

\section{Vernacular Radio Stations Programs and Public Participation in Governance}

Globally, community radio stations are recognized for their role in the advancement of good governance practices especially in reaching out to the marginalized in the society who include the poor, women and children (UNESCO, 2008). They also promote citizen's access to information which may enhance their participation in making decision at the county level especially in rural communities which have been denied access to information sharing and communication. Thus, countries like Nepal, Pakistan and India have taken steps that can encourage other nations to create conducive environment for community broadcasting to solve problems that are affecting the communities especially the youth who have turned to drug abuse. Wanyande (2004) also argues that the local radio programs provide an opportunity to the neglected in the society to enable them discuss issues that affect them. They also ensure advanced democratic process by being non-partisan during discussions on governance issues (Rahman, 2013). They also ensure duty bearers' accountability by involving the public and representatives from the civil society in their debates, talk shows, discussion programmes 
which create pressure on the government o deliver (James, 2014). In the United Kingdom, effective use of local media has brought about a healthy collaboration between the government and the civil society (Europe Institute of Public Participation, 2009).

The constitution of the United States requires the federal government to use all media platforms to engage the public in matters pertaining to the society (Nabatchi, 2017). Italy has a powerful social proficiency but poor in public trust for it makes use of strong civil society activity (Putnam, 1993) but the country has recently embraced media platforms as avenues to reach many people.

Africa has also not been left out in utilization of media platforms to address issues of concern, for education, information dissemination, entertainment, among other uses. For example, Somalia established a devolved structure in 2012 which were meant to be responsive to the needs of the locals. For this to be achieved, there must a strong relationship between the government and the citizens. Thus, United Nations and UNICEF Somalia joined hands to ensure dialogue between the locals and the local government officials. However, building such a strong relationship in Somalia is a challenge due to insecurity and infrastructure issues. Thus, interactive radio discussions driven by the listeners input via Short Message Services were put in place to engage the citizens in issues that concern them like security, role of local governance among others. This is because of the extensive mobile phone penetration and wide radio coverage in Somalia. More than 7 in 10 Somalis (72.4 percent) say they personally own a mobile phone and almost $84 \%$ use radio to access news at least once a week (Gallup, 2013). The discussions that ran for two months showed that locals are optimistic about local governments' performance. However, it recommends that future discussions needed to be improved in terms of content to better target elderly and those with less education and infrastructure so as to get to those in rural areas.

In South Africa, a study was carried out to understand youth priorities and to assess whether Livity's media campaign influenced young people's preference to vote in South Africa's 2016 municipal elections. Livity media believes young people are key to leading change in society; thus, it aims at engaging youth in society. The study revealed that the municipal elections were highly associated with online campaigns especially though Facebook. It further revealed that the online campaign was particularly important for the younger groups, new voters and those who initially had less interest in politics before the campaign. Livity concluded that the youth were discontented with the government, deemed it was biased, discriminatory and unjust in dealing with issues that concern them. It recommends that the future campaigns should be guided by the concerns and interests of young people so as to encourage them to take part in politics. In Mali, community radio stations have promoted levels of transparency and accountability in public resources management for they help to expose corruption and bribery (see Myers, 2006). Moreover, they have led to community cohesion as witnessed in Urban Youth radio in Senegal. Peace radio in northern Uganda and Township radio in South Africa. They have also significantly contributed in development of democracy and governance by providing information, education and entertainment

In Ghana, Purchase for Progress (P4P) joined hands with Radio International (FRI) to provide Ejura-Sekyeredumase district small-scale farmers with timely and necessary information on quality agricultural practices they needed to better their productivity in agriculture through the interactive radio programs which gave farmers a voice and education that assisted them to market quality crops to the World Food Programme (WFP) and other markets (Fiafor, 2014). This is because small-scale farmers have a challenge to meet quantity and quality requirements of formal markets due to lack of knowledge and skills. Although the majority of the rural farmers have little or no access to communication technologies (ICTs), in Ghana radio reaches at least $70 \%$ of rural households. Thus, it can be easily accessed by the citizenry with low academic qualifications for it can consumed in local languages. Thus, radio is a key medium to reach most small-scale farmers who are often found in rural areas that are a challenge to access. World Food Programme (WFP) provides markets for their produce which motivates them to use information from the radio programs so as to increase their produce in quantity and quality for home consumption and exchange at formal markets. As a result, the farmers have come to appreciate the significance of the information and are ready to invest in effective agricultural practices like application of fertilizer, planting in rows and proper storage of 
produce. In conclusion, farmers have also accessed markets for their produce where they receive fair prices (Fiafor, 2014)

Uganda has the exposure of devolution for two decades but there is inconsistency in level of public participation in local planning and putting local authority officials into accountability (KiyagaNsubuga \& Olum, 2009). A study on Public Participation in Services Delivery Projects in Buikwe District Local Government in Uganda reveals that public participation has gained broad recognition in local governance so as to enhance accountability in service delivery and enhance civic awareness. It further shows that public participation in local governance is highly influenced by the accessibility to information by the people, their ability to use the information effectively and their consciousness on their rights, roles and responsibilities. However, the information is not readily available for the citizenry to plan, monitor and evaluate the governments' projects. This is so because there is limited and expensive structure for handling information, limited abilities on how and when to utilize the information and lack of skills to analyze and simplify data for consumption. The study recommends that information sharing should be in an organized manner and should be carried out in a targeted and systematic way if the citizens are to be made aware of their rights, roles and responsibilities in service delivery which includes public participation in governance issues.

In Kenya, a study on 'Reporting on Devolution: How informative?' carried out by $W$ anaberi Centre (2014) assessed media coverage on devolution to examine its content aimed at ensuring balanced and informative reporting of the subject. The report revealed that there is need to focus on public participation in devolved governments if delivery of services by counties is to be achieved and for this to happen, media have a major role in information sharing, education and advocacy. It further showed that while devolution revolves around service delivery to the people, the media have highly concentrated on powers in charge of devolution. In interpreting public participation, the High Court of Kenya stated that public participation should be made real by use of many avenues like national and vernacular radio stations. The AfriMAP (2011) survey revealed that Kenya has a vast number vernacular radio stations that make use of local languages in dissemination of information and are also accessible in regions given little attention by the convectional commercial media. Moreover, a study on the Media We Want commissioned to investigate the factors that influence media behavior revealed that Kenya media users consume radio most followed by television and newspaper. They expose themselves to more than one channel per day and the majority prefers vernacular language media to English and Kiswahili. This finding indicates that vernacular radio stations can play a major role in informing the public on devolved governance processes and create platforms for public participation especially in marginalized areas and grassroots levels which result to diversity and pluralism for different views and opinions are heard. In conclusion, it is evident that there is a lot of data on use of media which includes social media and local radio to achieve various goals like sharing information and promotion of public participation in devolved governance but very little is done on how content of vernacular radio stations programs can influence public participation in devolved governance a gap which this study intended to fill.

\section{THEORETICAL FRAMEWORK}

\section{Agenda Setting Theory}

This study made use of agenda setting theory by McCombs and Donald Shaw in 1968 (McCombs, 1972). According to McCombs and Shaw the media have a role of setting the agenda among the audience, that is, they have the power to increase levels of importance attached to an issue by the audience (McCombs, 2005). The media not only informs the audience on what issues are important by highlighting them in terms of content, frequency, positioning, duration and timing but also influences their behavior. According to McCombs, the audience will regard an issue as more important if it is covered frequently and prominently by the media (McCombs, 1982). The theory is based on the assumption that when media give so much attention on issues and matters of concern, the public consider them with a lot of seriousness than others and it compares the salience of these issues and matters of concern in the media and then if the media has placed any form of influence in terms of guidance on them (McCombs, 2002). 
This theory was found applicable for this study because the concepts, constructs and relationships resident in it are as conceptualized and hypothesized in the current study. For instance, Vernacular Radio Stations programmes set the agenda by contributing to the content to be discussed during the interactive forums. As the theory claims, the media, in this case the vernacular radio stations programs, are likely to increase the level of importance the public attach to an issue- in this case issues of governance discussed during the interactive forums for they stress on them. This further influences public behaviour - which is their participation in issues of governance in the case of the current study.

\section{METHODOLOGY}

The study employed a mixed method research design in order to provide a comprehensive analysis of the research problem. Quantitative data included closed-ended responses in questionnaire on listeners of the vernacular radio stations programs while qualitative data included open-ended responses in interviews with officials of vernacular radio stations. The different types of data were collected by the researchers, separately analyzed and the results were compared to find out whether the findings confirmed or contradicted each other.

The study targeted Nyeri County residents. Nyeri has a population of 661,156 (Kenya National Bureau of Statistics, 2009) and is divided into six sub- counties: Kieni, Mathira, Mukurweini, Othaya, Nyeri Town and Tetu. The study also targeted the vernacular radio stations that have listenership in Nyeri: Coro FM, Gukena FM, Inooro FM, Kameme FM and Kieni FM. Purposive sampling technique was used to select three sub-counties: Kieni, Mathira and Nyeri town for they hosted the open forums at the time of research. Krejecie and Morgan pyramid method (1970) was used to establish overall sample size of 384 respondents. Purposive sampling technique was used to identify Kameme FM out of the five vernacular radio stations that have listenership in Nyeri for the station held the open forums at sub county level using a defined schedule during the research period. The forum was dubbed 'Action Station'. Purposive sampling technique was used to select three vernacular radio stations officials; the head of radio, the host and the producer of the program "Action Station" by Kameme FM. This is because the host presents the program; the producer has the necessary information about the program while the head of radio has all the information about the station.

\section{RESULTS}

The study sought to establish the level of public participation in devolved governance in Nyeri County. To do this, the respondents were required to indicate their opinion on the level of public participation in devolved governance. Figure 1 shows the level of public participation in governance.

Figure 1: Level of Public Participation in Devolved Governance in Nyeri County

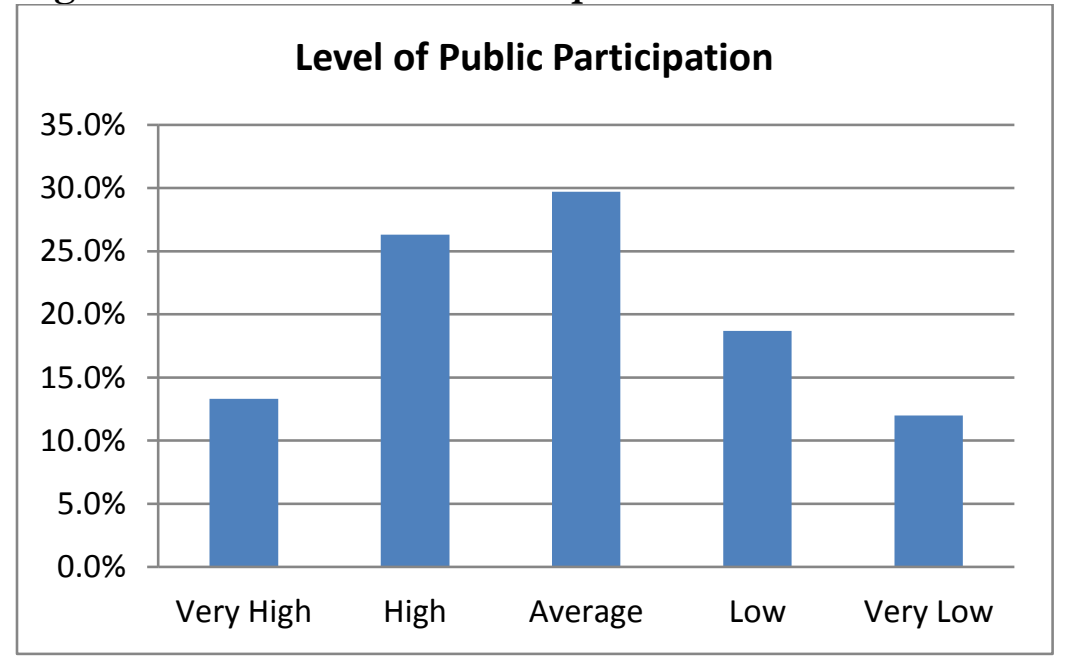

Source: Survey data (2017) 
Figure 1 indicates $13.3 \%$ and $26.3 \%$ of the respondents were of the opinion that the level of public participation was very high and high respectively; while $29.7 \%$ indicated it was average ,18.7\% thought it was low while $12 \%$ indicated it was very low. This means that the highest percentage of respondents was of the opinion that public participation in devolved governance was average. This is echoed by Institute of Economic Affairs (2015) report that revealed that Nyeri County is plagued with protests due to implementation of unpopular policies; an indication that public participation in issues of governance is low. This implies that a lot needs to be done to involve the public in issues of governance. This observation was voiced by the head of radio, the host and the producer of the program 'Action Station' of Kameme FM.

The head of radio stated,

"The level of public participation in devolved governance in Nyeri County is average especially through these forums for they have market meeting and town hall meeting format thus question and answer from participants. The public also participates through Radio call-ins, SMS and social media."

The host said,

"Public participation in devolved governance in Nyeri County is fair for a good number participates through different avenues like social media, live calls, SMS and attendance of public barazas."

The producer retorted,

"The level of public participation in devolved governance in Nyeri County is not very good. Out of ten, I would give it five. People should be more involved in decision-making in issues affecting them."

Relevance and Appropriateness of Content of Vernacular Radio Stations Programs (VRSP). The study sought to find out the relevance and appropriateness of VRSP content. The respondents were therefore asked to give their opinion on the level they agreed that the issues discussed in the programs were relevant and appropriate.

\section{Figure 2: Relevance and appropriateness of VRSP content}

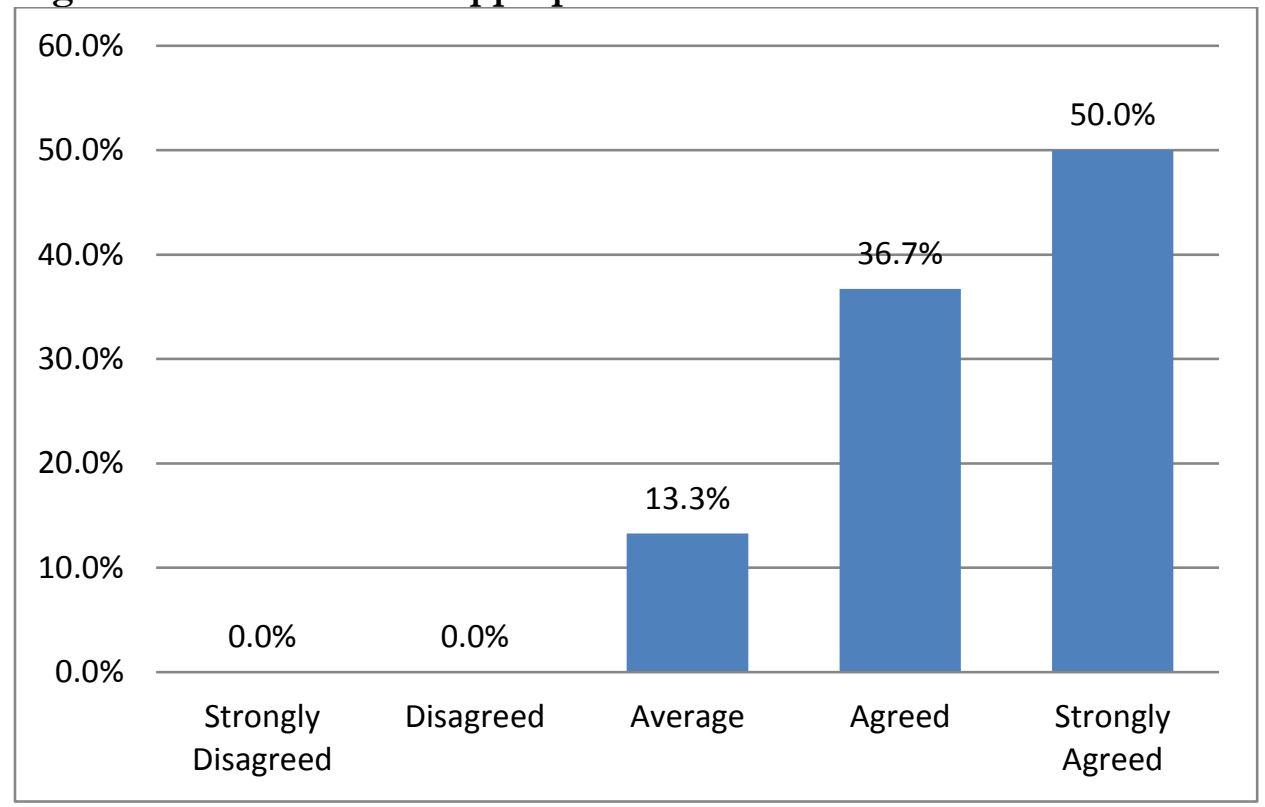

\section{Source: Survey data (2017)}

As Figure 2 reveals, the findings of the study indicated that $50 \%$ strongly agreed that the content was relevant and appropriate, $36.7 \%$ agreed $13.3 \%$ were neutral, $0.0 \%$ disagreed and $0.0 \%$ strongly disagreed. This means highest percentage of the respondents were of the opinion that content was 
relevant and appropriate. This observation was echoed by the head of radio, the producer, the host of the program 'Action Station' during the first interview.

The head of radio said,

"The content of the programs is very relevant and appropriate to the general public for it cuts across the issues affecting them. They include among others devolution, Agriculture, Health, distribution of resources, job creation, security, politics, and youth and women funds."

The producer retorted,

"The content of these programs is highly appropriate since the programs are participatory and bulky of the information coming from the residents thus the people are able to set their own agenda."

The host said,

"The content is quite relevant for the listeners and county residents for they understand better the role of devolved governance and its mandate. This is because the programs tend to educate the residents and listeners on the role of each member in leadership; that is, Members of County Assembly, Member of Parliament, Governor, Senator etc.

The Relationship between Vernacular Radio Stations Programs Content and Public

Participation in Devolved Governance in Nyeri County.

Table $1 \quad$ VRSP Content and Public Participation in Devolved Governance

Correlation VRSP Public Participation in

Content Devolved Governance

VRSP Content

Pearson Correlation

$1.705^{* *}$

Sig. (1-tailed) $\quad-\quad 000$

$\mathrm{N} \quad 145 \quad 145$

$\begin{array}{llll}\text { Public Participation in } & \text { Pearson Correlation } & .705^{* *} & 1 \\ \text { Devolved Governance } & \text { Sig. (1-tailed) } & .000 & - \\ & \text { N } & 145 & 145\end{array}$

**. Correlation is significant at the 0.01 level (1-tailed test)

Source: Survey data (2017)

Table 1 shows that the correlation between VRSP content and public participation in devolved governance in Nyeri County is strongly positive as shown by correlation of 0.705 . The p-value of 0.000 is less than the significance level (0.01). Therefore, VRSP content strongly influences the public participation in devolved governance in Nyeri County at 95\% confidence level.

\section{DISCUSSION}

Vernacular Radio Stations Programs Content analysis was performed using descriptive and inferential techniques. It was found that Vernacular Radio Stations Programs (VRSP) Content strongly influences the public participation in devolved governance in Nyeri County.

The highest number of the respondents (30\%) strongly agreed that the content of vernacular radio stations programs is relevant and appropriate. This was echoed by interviewees who were of the opinion that the content cuts across issues that affect the county residents. This observation is also depicted in the coefficient of correlation testing of +0.705 . This finding is in agreement with the agenda-setting theory as proposed by McCombs (1972) which claims that media have a role in setting the agenda by highlighting the issues considered important. This is evident in the current study in that 
the issues discussed during the vernacular radios stations programs are highly regarded by the audience for they revolve around the issues that concern them.

This can be attributed to the fact that majority of the respondents were for the opinion that the topics of county governance discussed in the programs are relevant, appropriate and of great concern to them. In addition, the issues are raised by the residents themselves for these forums are interactive and residents are given the opportunity to raise issues of their concern. The topics discussed mainly included agriculture, health, roads, education, employment, effectiveness and efficiency of service delivery by the county representatives and Women and Youth funds among others.

This study found that the audience participated in issues governance discussed with a lot of ease as revealed for they revolved around the issues of their concern. This is as revealed by the coefficient of correlation of +0.705 . This observation also concurs with the agenda-setting theory which further claims that media not only sets the agenda but also influence the behavior of the audience. This is also revealed in this study in the fact that the topics highlighted in the interactive forums are highly regarded by the audience; thus, influencing their high level of participation in governance.

\section{CONCLUSION AND RECOMMENDATIONS}

The study has concluded that there exists a positive relationship between vernacular radio programming content and participation of community in issues of governance. Therefore, it is recommended that vernacular radio stations should give more attention to the content of these programs. Priority should be given to issues that are raised by the audience for they are pertinent to them. This will result in more public participation in matters of county governance in Kenya.

\section{REFERENCES}

AfriMAP (2011). Kenya: Public Broadcasting Survey. Nairobi: African Minds.

Barret, C., Mude, A., \& Omiti, M. (2007). Decentralization and the Social Economics of Development: Lessons from Kenya. Wallingford: CAB International.

Cheema, G., (2007). Devolution with Accountability: Learning from Good Practices. In: Cheema, G. S. \& Rondinelli, D. A., (Eds.). 2007. Decentralizing Governance: Emerging Concepts and Practices. Washington: Brookings Institution Press. pp. 170-188

Chirisa, I. \& Banduko, E. (2014) Debating the inconsistencies between Constitutional Provisions on Decentralization and Citizen Participation Realities in Zimbabwe. Journal of Governance and Development, (10): 1-18

Dunu, I. (2013). Good Governance in Nigeria: what Role for the Media. European Scientific Journal, ESJ $9(32)$

Fiafor, B, (2014). How Radio Programmes can support Agriculture and Market Development. Ottawa: Farm Radio International. https://reliefweb.int/report/ghana/how-radio-programmes-cansupport-agriculture-and-market-development.

Gallup. N.d. About Gallup. http://www.gallup.com/Corporate/177680.aspx. (Accessed 23 February 2015).

GFMD (eds). (2006). Global Forum for Media Development. Paris: InterNews. 
Institute of Economic Affairs, (2015). Review of status of Public Participation, and County Information Dissemination Frameworks: Case Study of Isiolo, Kisumu, Makueni and Turkana Counties. Nairobi: Institute of Economic Affairs.

James, B. (2014). Media and Good governance. The United Nations Educational, Scientific and Cultural Organization, 15-57. Paris: UNESCO.

Kakumba, U. (2010) Local Government Citizen Participation and Rural Development: Reflections on Uganda Decentralization Systems. Makerere University, Kampala: Uganda.

Kenya National Bureau of Statistics. (2009) Kenya Population and Housing Census. Nairobi: Kenya.

Khaunya, M., Wawire, B., \& Chepngeno, V. (2015). Devolved Governance in Kenya: Is it a False Start in Democratic Decentralization Development? International Journal of Economics, Finance and Management, 4. http:/ / www.ejournalofbusiness.org/archive/vol4no1 / vol4no1 4.pdf

Kimutai, C. (2011). Research shows radio is king in Kenya. bttp:/ / www.bizcommunity.co.ke/PDF/PDF.aspx?l=111\&c=19\&ct=1\&ci=6855. (Accessed 26 May, 2012)

Kiyanga-Nsubuga, J. \& Olum, V. (2009). Local Governance and Local Democracy in Uganda, Commonwealth Journal of Local Governance 2: 26-43. bttp:// epress.lib.uts.edu.au/journals/index.php/cjlg/article/view/1006

Krejecie, R., \& Morgan, D. (1970). Determining Sample Size for Research Activities. Educational and Psychological Measurement, 30:607-610.

Kugonza, s. \& Mukobi, R. (2015). Public Participation in Services delivery projects in Buikwe District Local Government Uganda. Commonwealth Journal of Local Governance 18:4846http:/dox.doi.org/10.5130/cjlg.v0i18:4846

Lodiaga, M. (2012). Contextual Constraints Affecting Women Participation in Local Governance. The Kenyan Case Study.

McCombs, M and Shaw, D. (1972). The Agenda-Setting Function of Mass Media. Public Opinion Quarterly, 36(2): 176-187.

McCombs, M. (2005). A look at agenda-setting: Past, present and future. Journalism Studies, 6: 543-557.

McCombs, M.E. (1972). Mass Communication in Political Campaigns: Information, Gratification and Persuasion. In: Kline, F. \& Tichenor, P.J. (Eds.) Current Perspectives in Mass Communication Research. Beverly Hills: SAGE.

McCombs, M.E. (1982). The Agenda-Setting Approach. In: Nimmo, D. \& Sanders, K. (Eds.) Handbook of Political Communication. Beverly Hills, CA: Sage.

McCombs, M.E. and A. Reynolds (2002) "News Influence on our Pictures in the World ", In J. Bryant and D. Zillmann (Eds.) Media Effects: Advances in Theory and Research, (2 ${ }^{\text {nd }}$ edn.). pp.1-16. Hillsdale, NJ: Lawrence Erlbaum

Muriu, A. (2012). Decentralization, citizen participation and local public service delivery. A study on the nature and influence of citizen participation on decentralized service delivery in Kenya. Master's degree thesis, Universität Potsdam.https://www.econstor.eu/bitstream/10419/104749/1/749929790.pdf 
Myers, M. (2008). Local radio: fostering community development or ethnic hatred? Donor dilemmas and perspectives from Rwanda, D.R. Congo and Kenya. Paper presented at University of Westminster, CAMRI conference 'The Media and Development in Africa' 27-28 March 2008. http://www.marysophiamyers.org/pdfs $\% 20$ of $\% 20 \mathrm{my}^{\circ} \% 20$ publications $/ 6 \% 20 \mathrm{Local} \% 20$ Radi o.pdf

Nabatchi, T. (2010). Deliberative Democracy and Citizenship: In Search of the Efficacy Effect," Journal of Public Deliberation. Vol. 6(2):1-47

National Council for Law Reporting, (2010), Constitution of the Republic of Kenya http://www.kenyalaw.org/klr/fileadmin/pdfdownloads/Acts/ConstitutionofKenya20 10.pdf. (Accessed January 11, 2016).

Ogundiya, I. (2010). Democracy and Good Governance: Nigeria's Dilemma. Nigeria’s dilemma. African Journal of Political Science and International Relations, 4(6): 201-208.

Panos, (2007). The Case for Communication in Sustainable Development. London: Panos Institute

Putnam, R. (1993). Making Democracy Work: Civic Traditions in Modern Italy, Princeton: Princeton University Press.

Rahman, A. B. (2013). The Role of Community Radio in Establishing Good Governance through Right to Information in Bangladesh. Dhaka: Sage publication

Ronoh, G., Mulongo, S. \& Kurgat, A. (2018) Challenges of Integrating Public Participation in Devolved System of Governance for Sustainable Development in Kenya. International Journal of Economics, Commerce and Management: Vol. 6 (1). http://ijecm.co.uk/wpcontent/uploads/2018/01/6132.pdf

Stivers, M. (2010). Institutional Transformation and Status Mobility: The Professionalization of the Field of Finance. Academy of Management Journal, 45: 255-266

Transparency International, (2015). Uongozi Mashinani. A national opinion poll on devolution and governance in Kenya. Nairobi: Government Printer

UNESCO. (2008). Communication for Development. London: Sage Publication.

University of Nairobi. (1991). Working with Rural Communities. A participatory Action. Nairobi: University Press.

Wanyande, P. (2004). Decentralization and Local Governance: A Conceptual and Theoretical Discourse. In: Regional Development Dialogue Journal of the United Nations Center for Regional Development (UNCRD), 25 (1):1-13.

Waters, D., James, R. \& Darby, J. (2011). Health Promoting Community Radio in rural Bali: an impact evaluation. https://www.ncbi.nlm.nih.gov/pubmed/21375357.

World Bank. (2015). Building public participation in Kenya's devolved government. Kenya School of Government. CDS paper 1-6 series. 